\title{
An analysis of the resistance of an extended end-plate beam-to-beam connection subjected to tension in fire conditions
}

\author{
Alina Słowikowska ${ }^{1}$, Lukasz Polus ${ }^{2}$ \\ ${ }^{1}$ Institute of Structural Engineering, Faculty of Civil and Environmental Engineering, \\ Poznan University of Technology, e-mail: alina.slowikowska@student.put.poznan.pl \\ ${ }^{2}$ Institute of Structural Engineering, Faculty of Civil and Environmental Engineering, \\ Poznan University of Technology, e-mail: lukasz.polus@put.poznan.pl
} ORCID: 0000-0002-1005-9239

\begin{abstract}
This paper presents an analysis of the fire resistance of a steel joint subjected to tension. The authors of this article used prescriptive rules and simple calculation models to present an impact of the value of the load on the fire resistance of the connection. Designers often evaluate the critical temperature and fire resistance time of steel elements. However, they neglect the evaluation of the above-mentioned values for steel connections. In this article a simple engineering method was used to calculate the fire resistance of the joint.
\end{abstract}

Keywords: beam-to-beam connection, fire resistance, steel joint, critical temperature.

\section{Introduction}

The fire design of bolted and welded joints is presented in [1-6]. The steel temperature in the joint is always lower than in the element due to the presence of the additional material [7]. The mechanical behaviour of steel joints at elevated temperatures is an important scientific problem, because beam-to-column and beam-to-beam connections are often used in steel structures. The results of the fire tests of these joints were presented in [8].

Malendowski et al. presented a new type of beam-to-column connection [9]. This joint is capable of absorbing both very large rotations and axial movements, due firstly to the thermal elongation and subsequently to the extreme weakening of the connected beam. Maślak and Litwin evaluated the reduction of the beam-to-column joint stiffness under fire conditions [10]. The stiffness of the joints decreases as the fire develops [11]. The problem with flexible joints in fire conditions was presented in $[12,13]$. The ductility and the failure of the joint may be evaluated using the component method and a simplified mechanical model with extensional springs and rigid links [14]. A component-based element for endplate connections in fire conditions was described in [15].

Connections may be subjected only to tension, e.g. an extended end-plate beam-tobeam connection used in the bottom chord of the truss. This type of connection is analysed in this article. The fire resistance of this joint is rarely evaluated by designers, even though it may be easily determined using the method described in Annex D of [2]. 


\section{Problem formulation}

The authors of this article used a simple method presented in Annex D of [2] to present the impact of the value of the load on the fire resistance of the extended end-plate beam-to-beam connection subjected to tension. The authors tried to answer the question of what the degree of utilisation of the unprotected bolted joint should be to fulfil the fire resistance criterion R15 for this connection. An unprotected construction needs more steel than a fire protected construction to fulfil the said fire resistance criterion. However, the use of unprotected structural elements and joints may provide for the reduction of the total costs of the construction, because fire protection materials are expensive.

During the analysis, the authors used prescriptive rules:

- a standard fire [16] was used to heat up the joint,

- the effects of actions were determined for time $t=0$,

- indirect fire actions were not taken into consideration,

- the boundary conditions at the supports and ends of the member were assumed to remain unchanged throughout the time of fire exposure,

- different reduction factors were assumed for structural steel, bolts and welds (see Fig. 1),

- a uniform distribution of temperature was assumed,

- the $A / V$ ratio of the joint was assumed as the maximum value of the $A / V$ ratios of the connected steel members adjacent to the joint,

- the design value of the tension force in a fire situation was obtained from the value at normal temperature using the reduction factor $\eta_{f i}=0.65$,

- the critical temperature of the joint was calculated using the iterative method, presented e.g. in $[17,18]$.

- equivalent T-stub flanges were used to model the joint and to evaluate the design resistance of the end-plate.

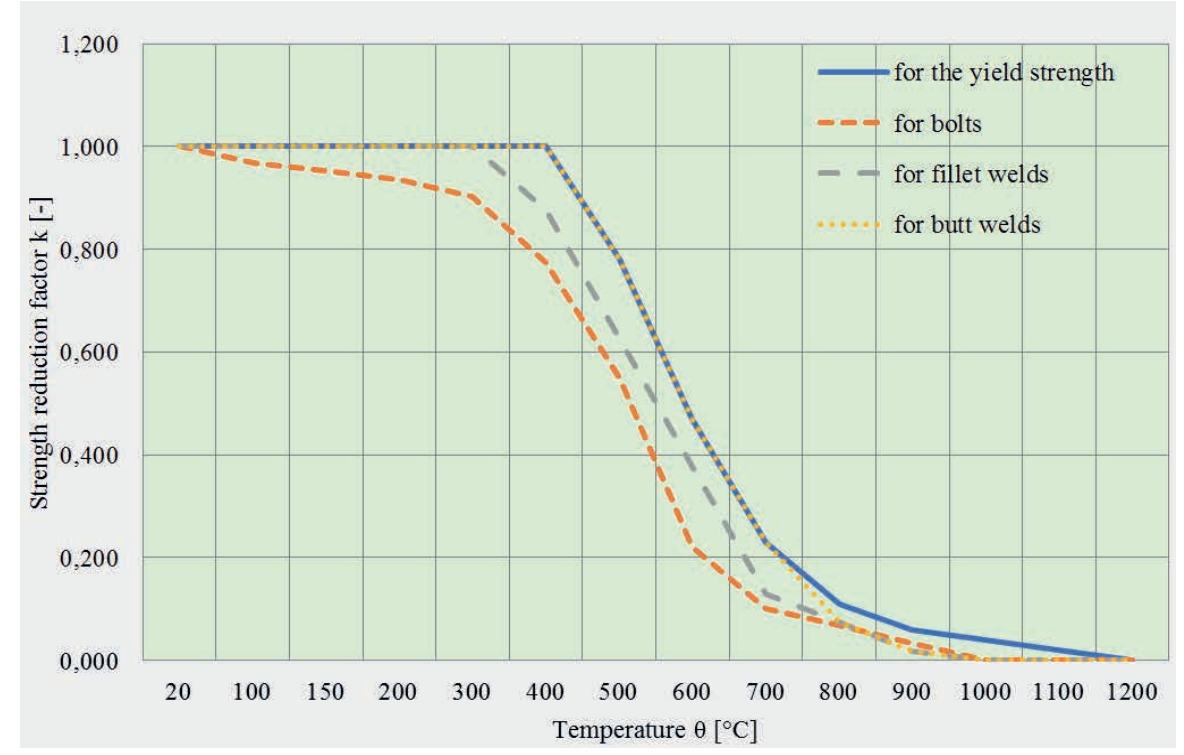

Fig. 1. Reduction factor for structural steel, bolts and welds 
According to Maślak et al., the assumption that the temperature in a joint is uniformly distributed is safe [19]. What is more, the assumption that the temperature is calculated using the maximum value of the $A / V$ ratios of the connected steel members adjacent to the joint is also conservative, and so is the assumption that the design value of the tension force in a fire situation is obtained from the value at normal temperature using the reduction factor $\eta_{f i}=0.65[1]$.

In Figure 1 one can see that the strength of the bolt decreases faster than the strength of the steel in the extended end-plate. For this reason the mode of failure of a joint in a fire situation may be different than at normal temperature. For example, at normal temperature, the failure of a T-stub flange may consist of the bolt failure and the yielding of the flange, whereas in the fire situation it may consist of the bolt failure only.

\section{Engineering example}

In this paper the S355 bolted tension joint was analysed (see Fig. 2). Grade 8.8., M30 bolts were used. The design values of tension forces at normal temperature and in a fire situation are presented in Table 1. The value of the tension force was varied from 20 to $60 \%$ of the cross-section design resistance of the connected beam at normal temperature. The transfer of tensile force in the connection was achieved through the end-plate in bending components. The evaluation of the resistance of such components was based on a geometrical idealisation of tension zone (T-stub idealisation) [20, 21]. The formulas presented in $[2,21]$ were used to determine the resistance of the joint.
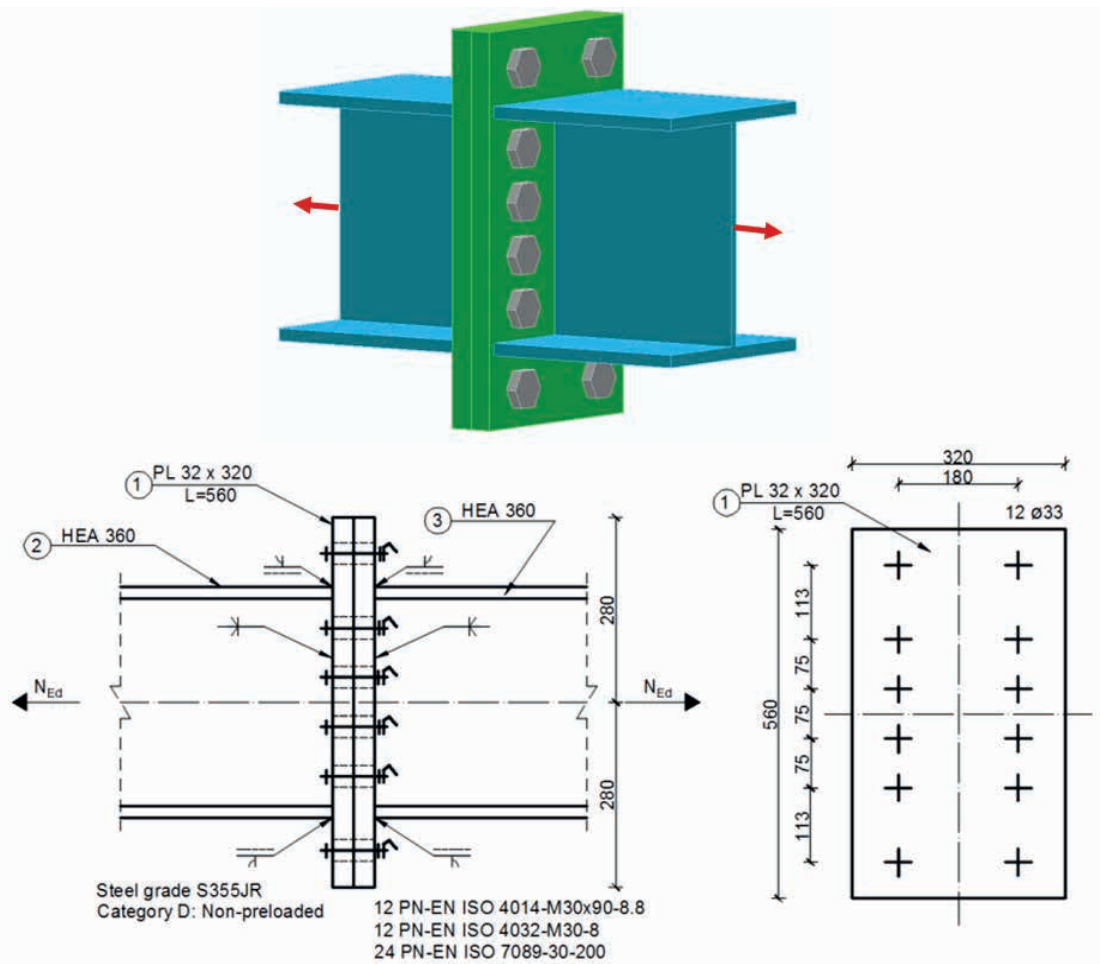

Fig. 2. Analysed joint 
Table 1. Design values of the tension forces at normal temperature and in a fire situation

\begin{tabular}{cc}
\hline \multicolumn{2}{c}{ Design values of the tension forces } \\
\hline At normal temperature & In a fire situation \\
\hline$N_{E d}[\mathrm{kN}]$ & $N_{f i, E d}[\mathrm{kN}]$ \\
\hline $3045.9\left(0.6 N_{c . R d^{*}}\right)$ & $1979.8\left(0.39 N_{c . R d^{*}}\right)$ \\
$2538.3\left(0.5 N_{c . R d^{*}}{ }^{*}\right)$ & $1675.2\left(0.33 N_{c . R d^{*}}\right)$ \\
$2030.6\left(0.4 N_{c . R d^{*}}{ }^{*}\right)$ & $1319.9\left(0.26 N_{c . R d^{*}}\right)$ \\
$1523.0\left(0.3 N_{c . R d^{*}}{ }^{*}\right)$ & $1015.3\left(0.20 N_{c . R d^{*}}\right)$ \\
$1015.3\left(0.2 N_{c . R d^{*}}\right)$ & $659.9\left(0.13 N_{c . R d^{*}}\right)$ \\
\hline
\end{tabular}

${ }^{*}$ Cross-section design resistance of HEA 360 at normal temperature

The resistance of the T-stub involving a group of bolt-rows was calculated along with the resistance of the individual T-stubs. The lowest of joint resistance value was chosen (3165.03 kN) (see Fig. 3).

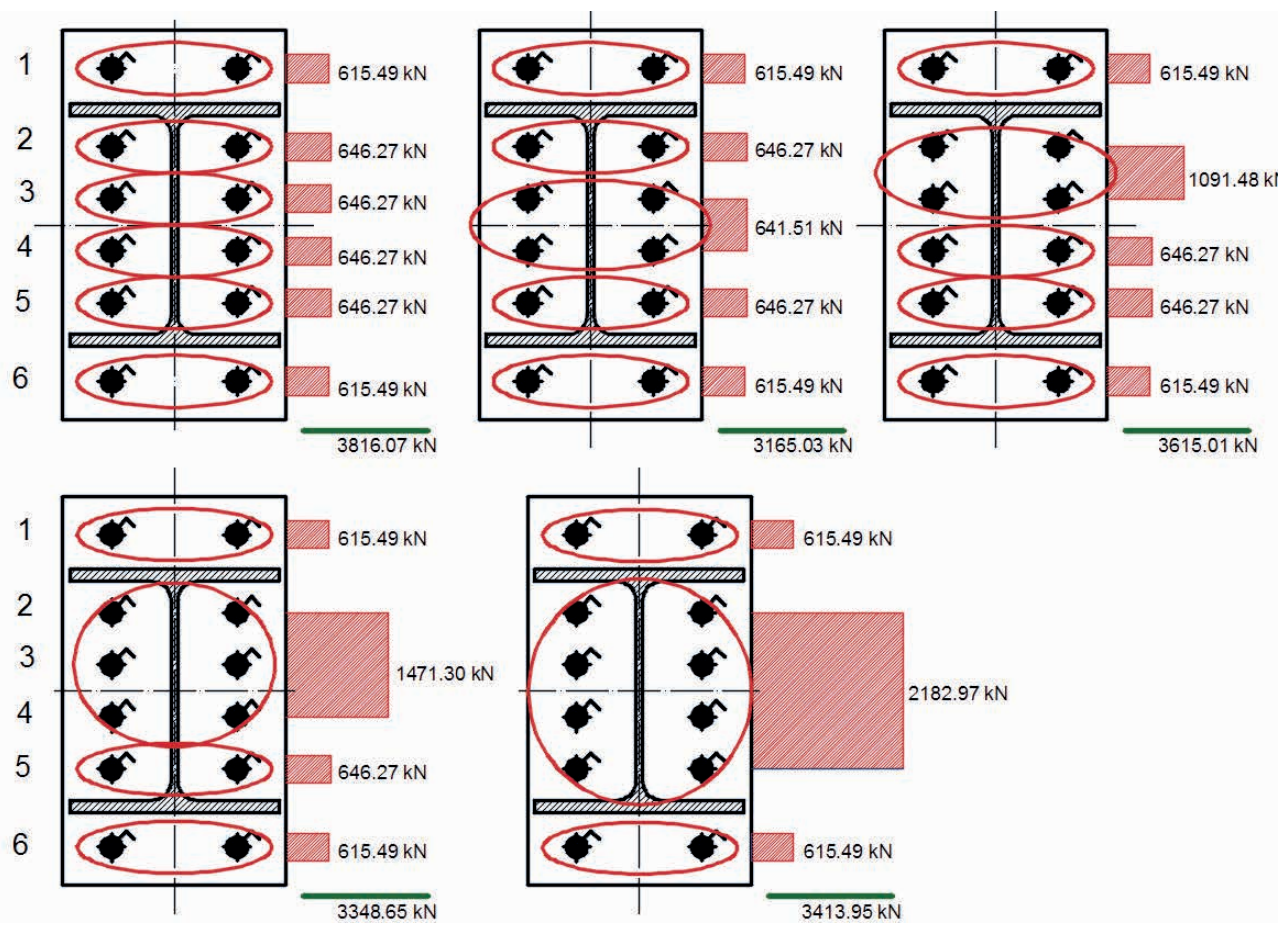

Fig. 3. Resistance of the joint at normal temperature

The $A / V$ ratio of the joint was assumed as the $A / V$ ratio for the tension member - HEA $360(A / V=128.31 / \mathrm{m})$. The shadow effect was neglected $\left(k_{s h}=1.0\right)$. The critical temperature of the joint was calculated using the iterative procedure. The temperature was increased until the degree of utilisation of the joint reached about 1.0. The resistances of structural steel, bolts and welds decreased as temperature increased (see Fig. 1). For example, the resistance of the joint at $500{ }^{\circ} \mathrm{C}(2277.61 \mathrm{kN})$ is presented in Fig. 4. 

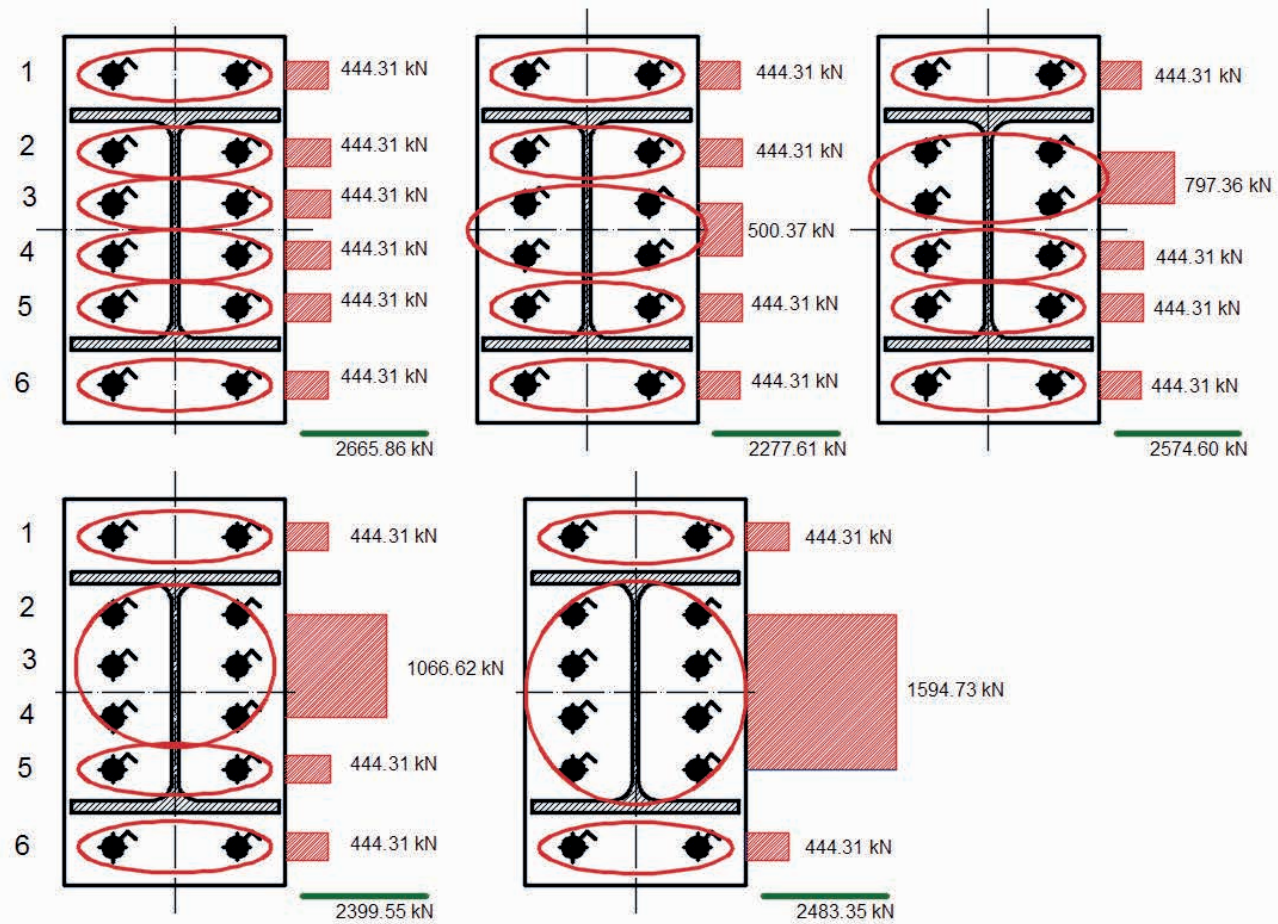

Fig. 4. Resistance of the joint at $500{ }^{\circ} \mathrm{C}$

The critical temperatures of the joint depending on the tension force are presented in Fig. 5.

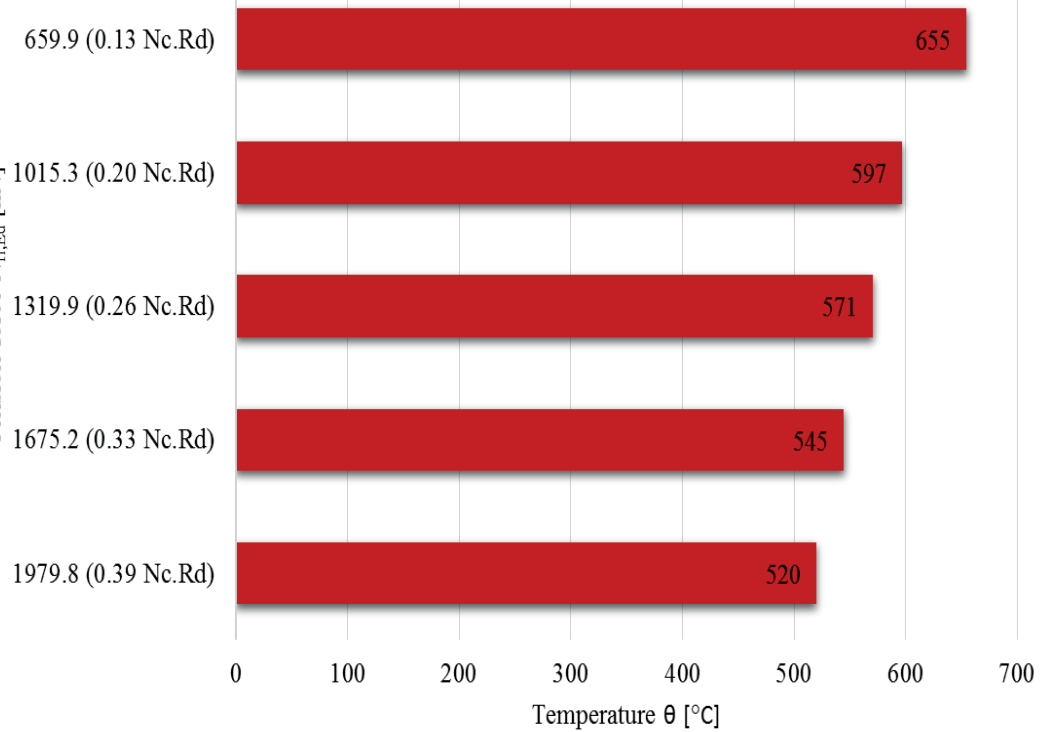

Fig. 5. The critical temperatures of the joint depending on the tension force 
After the evaluation of the critical temperature of the joint, the fire resistance time was calculated (see Fig. 6). A standard fire was used to heat up the joint.

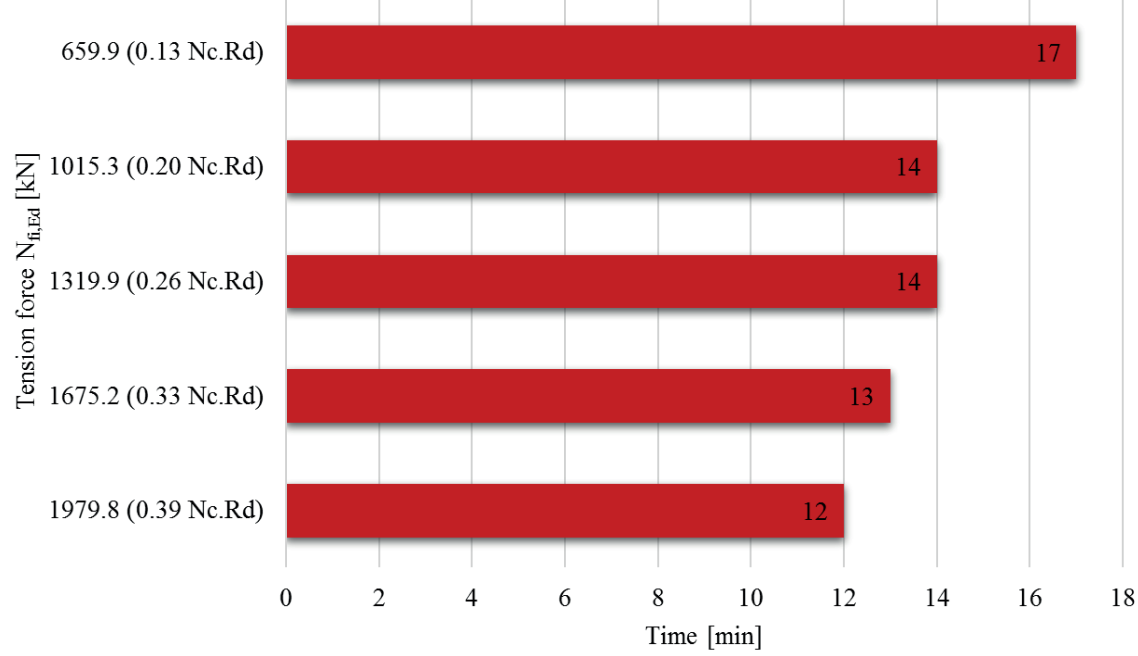

Fig. 6. Fire resistance time of the joint depending on the tension force

The results of the analysis are presented in Table 2 . One can see that the value of the load had an impact of the fire resistance of a connection. The connection with the degree of utilisation of 0.96 had a fire resistance of 12 minutes, whereas the joint with the degree of utilisation of 0.32 had a fire resistance of 17 minutes. An unprotected bolted joint may fulfil the fire resistance criterion R15. However, the degree of utilisation of the joint at normal temperature should be low (0.32 in this paper).

Table 2. Results of the analysis

\begin{tabular}{|c|c|c|c|c|}
\hline \multicolumn{2}{|c|}{ At normal temperature } & \multicolumn{3}{|c|}{ Fire situation } \\
\hline $\begin{array}{c}\text { Tension force } \\
\qquad N_{E d} \\
{[\mathrm{kN}]}\end{array}$ & $\begin{array}{c}\text { Degree of } \\
\text { utilisation } \\
{[-]}\end{array}$ & $\begin{array}{c}\text { Tension force } \\
\qquad N_{f i, E d} \\
{[\mathrm{kN}]}\end{array}$ & $\begin{array}{c}\text { Critical } \\
\text { temperature } \\
{\left[{ }^{\circ} \mathrm{C}\right]}\end{array}$ & $\begin{array}{c}\text { Fire resistance } \\
\text { time } \\
{[\mathrm{min}]}\end{array}$ \\
\hline $3045.9\left(0.6 N_{c . R d^{*}}{ }^{*}\right)$ & 0.96 & $1979.8\left(0.39 N_{c . R d}{ }^{*}\right)$ & 520.0 & 12 \\
\hline $2538.3\left(0.5 N_{c . R d^{*}}\right)$ & 0.80 & $1675.2\left(0.33 N_{c . R d^{*}}\right)$ & 545.0 & 13 \\
\hline $2030.6\left(0.4 N_{c . R d^{*}}{ }^{*}\right)$ & 0.64 & $1319.9\left(0.26 N_{c . R d^{*}}{ }^{*}\right)$ & 571.0 & 14 \\
\hline $1523.0\left(0.3 N_{c . R d^{*}}\right)$ & 0.48 & $1015.3\left(0.20 N_{c . R d^{*}}{ }^{*}\right)$ & 597.0 & 14 \\
\hline $1015.3\left(0.2 N_{c . R d^{*}}{ }^{*}\right)$ & 0.32 & $659.9\left(0.13 N_{c . R d}{ }^{*}\right)$ & 655.0 & 17 \\
\hline oss-section design & ce of $\mathrm{H}$ & 0 at normal temperat & & \\
\hline
\end{tabular}

\section{Conclusions}

The main conclusions of this paper are:

- The fire resistance of a joint subjected to tension is easy to determine using the method presented in Annex D of [2]. 
- The fire resistance of extended end-plate beam-to-beam connections subjected to tension strongly depends on the bolt strength, because the strength of the bolt decreases faster than the strength of the steel in the extended end-plate.

- The value of the load has an impact on the fire resistance of a connection.

- An unprotected bolted joint may fulfil the fire resistance criterion R15 when the degree of utilisation of the joint at normal temperature has a low value (e.g. 0.32 in this paper).

\section{References}

[1] Franssen J.M., Real P.V. Fire design of steel structures. Eurocode 1: Actions on structures, Part 1-2: Actions on structures exposed to fire, Eurocode 3: Design of steel structures, Part 12: Structural fire design. ECCS, 2010.

[2] European Committee for Standardization. EN 1993-1-2 Eurocode 3: Design of steel structures - Part 1-2: General rules - Structural fire design. Brussels, 2005.

[3] Maślak M. Trwatość pożarowa stalowych konstrukcji prętowych. Wydawnictwo Politechniki Krakowskiej, 2009 [in Polish].

[4] Gwóźdź M., Suchodoła M. Bezpieczeństwo pożarowe budowlanych konstrukcji metalowych. Wydawnictwo Politechniki Krakowskiej, 2016 [in Polish].

[5] Turkowski P., Sulik P. Projektowanie konstrukcji stalowych z uwagi na warunki pożarowe wedtug Eurokodu 3, Warszawa, Instytut Techniki Budowlanej, 2015 [in Polish].

[6] Kurzawa Z., Polus Ł., Szumigała M. Stany graniczne $i$ odporność pożarowa elementów stalowych wedtug Eurokodu 3. Wydawnictwo Politechniki Poznańskiej, 2016 [in Polish].

[7] Franssen J. M., Brauwers L. Numerical determination of 3D temperature fields in steel joints. Second International Workshop: Structures in Fire, Christchurch, New Zealand, 2002.

[8] Wald F., Simoes da Silva L., Moore D., Santiago A. Experimental behavior of steel joints under natural fire. ECCS - AISC Workshop: Connections in Steel Structures, Amsterdam, The Netherlands, 2004.

[9] Malendowski M., Burgess I., Glema A. Robustness in fire of a new type of beam-to-column connection, [in:] ce/papers, Special Issue: Proceedings of Eurosteel 2017, Ernst \& Sohn, Volume 1, Issue 2-3, pp. 550-559, 2017, doi: 10.1002/cepa.92.

[10] Maślak M., Litwin M. Flexibility of beam-to-column steel joint under fire temperature. Inżynieria i Budownictwo 66(8) (2010) 441-454 [in Polish].

[11] Maślak M., Pazdanowski M., Snela M. Moment-rotation characteristics for flexible beam-tocolumn steel joint exposed to fire. Journal of Civil Engineering and Architecture 9 (2015) 257 261, doi: 10.17265/1934-7359/2015.03.002.

[12] Maślak M., Pazdanowski M., Snela M., Numerically-based quantification of internal forces generated in a steel frame structure with flexible joints when exposed to a fire, [in:] Advances in Mechanics: Theoretical. Computational and Interdisciplinary Issues - 3rd Polish Congress of Mechanics, PCM 2015 and 21st International Conference on Computer Methods in Mechanics. (ed. Kleiber M. et al.). CRC Press, pp. 389-392, London 2016.

[13] Maślak M., Pazdanowski M., Snela M., Redistribution of internal forces generated in a steel frame structure with flexible joints when exposed to a fire, [in:] Recent Progress in Steel and Composite Structures - Proceedings of the 13th International Conference on Metal Structures (ICMS2016, Zielona Góra, Poland, 15-17 June 2016). (ed. Giżejowski M. et al.). CRC Press, pp. 315-322 London 2016.

[14] Simoes da Silva L., Santiago A., Real P.V. Post-limit stiffness and ductility of end-plate beamto-column steel joints. Computers \& Structures 80 (2002) 515-531, doi: 10.1016/S00457949(02)00014-7.

[15] Block F., Burgess I., Davison B., Plank R. The development of a component-based connection 
element for endplate connections in fire. Fire Safety Journal 42(6-7) (2007) 498-506, doi: 10.1016/j.firesaf.2007.01.008.

[16] European Committee for Standardization. EN 1991-1-2 Eurocode 1: Actions on structures Part 1-2: General actions - Actions on structures exposed to fire. Brussels, 2002.

[17] Szumigała M., Polus Ł. A comparison of the rise of the temperature of an unprotected steel column subjected to the standard fire curve ISO 834 and to a natural fire model in the office. Engineering Transactions 63(2) (2015) 157-170.

[18] Szumigała M., Polus Ł. Fire resistance of the ceiling in the old tenement house. Procedia Engineering 195 (2017) 178-182, doi: 10.1016/j.proeng.2017.04.541.

[19] Maślak M., Suchodoła M., Woźniczka P. Temperature distribution in a steel beam-to-column joint when exposed to fire. Part 1: End-plate joint. Journal of Civil Engineering, Environment and Architecture 65(2) (2018) 25-34, doi: 10.7862/rb.2018.21.

[20] Jaspart J. P., Weynand K. Design of joints in steel and composite structures, Eurocode 3: Design of steel structures, Part 1-8: Design of joints, Eurocode 4: Design of composite steel and concrete structures. ECCS, 2016.

[21] European Committee for Standardization. EN 1993-1-8 Eurocode 3: Design of steel structures - Part 1-8: Design of joints. Brussels, 2005. 